https://doi.org/10.48009/1_iis_2010_372-376

\title{
CLINICAL RESEARCH: USING BUSINESS INTELLIGENCE FRAMEWORK
}

\author{
Terri L. Keeling, Robert Morris University, tkeeling@upmc.edu
}

\begin{abstract}
The 2009 American Recovery and Reinvestment Act (2009 ARRA) promotes the use of Healthcare Information Technology (HIT) and Electronic Health Records (EHR). As EHR applications proliferate in academic partnered or affiliated healthcare systems, clinical researchers should engage in EHR initiatives and apply a Business Intelligence (BI) framework to optimize clinical research processes to transform EHR data into knowledge. With the use of Clinical Research Analytics (CRA), tools and techniques such as clinical research decision support systems (CRDSS), data mining, and ad hoc reporting can be used for research processes such as data collection and analysis. With the establishment of Clinical Research Informatics (CRI) and Clinical Research Intelligence (CLRI), clinical researchers can leverage data intelligence strategies and optimize the clinical research process.
\end{abstract}

Keywords: Clinical Research Informatics; Business Intelligence; Electronic Health Records; Clinical Research Intelligence; Business Analytics; Clinical Research Analytics; Decision Support; 2009 ARRA

\section{INTRODUCTION}

Congress and President Obama signed the 2009 American Recovery and Reinvestment Act (2009 ARRA) which includes the intent to impose incentives and penalties on healthcare entities in effort to promote the use of Health Care Information Technology (HIT) [1]. The Act includes a section, Subtitle A, Promotion of Health Information Technology (HIT), that is dedicated to the improvement of health care quality, safety, and efficiency by increasing coordination of care among healthcare providers, reducing the number of medication administration and medical errors, and improving public health [1]. This transformation of data collection, storage, and retrieval presents an opportunity for clinical researchers to have access to a high volume of clinical data in digital format.

The electronic health record (EHR) provides the potential through clinical documentation, decision support, and interoperability (integration with other systems) to prevent adverse events, reduce medication errors, and improve patient safety and quality of patient care in the healthcare setting [3]. The patient medical record is undergoing a paradigm shift from a paper-based or hybrid (paper-based with some electronic documentation) record to a fully integrated electronic medical record. While there is great benefit to be realized from a clinical perspective, there is limited literature dedicated to the benefits that could be gained by clinical researchers. EHR data collection and storage could potentially enhance the clinical research process in hospital settings, presented a paradigm shift in the recruitment and data collection and analysis process. With electronic documentation, organization, and storage, clinical researchers in an academic partnered or affiliated healthcare system can benefit from the increased accessibility of electronic information. Further, clinical researchers can apply a Business Intelligence (BI) framework to create Clinical Research Intelligence (CLRI) frameworks to optimize the data collection and analytics. As the healthcare industry undergoes this paradigm shift, clinical researchers are presented with the opportunity and challenge to acquire knowledge using a BI approach to recruit participants, collect data, perform analysis, and possibly assist in the generation of hypotheses.

\section{INNOVATIVE USE OF THE ELECTRONIC HEALTH RECORD (EHR) FOR RESEARCH INITIATIVES}

Powell and Buchan recognized an opportunity to leverage the EHR for the benefit of research. Using clinical decision support-rules and alerts-- in the EHR, candidates for a clinical trial were identified at the time of the patient encounter with the physician. During the patient encounter, if the patient met the criteria for a clinical trial, an alert fired to alert the attending physician that the patient was a potential candidate for the trial. The physician was presented with two options: 1) disregard and continue, or 2) accept and enroll patient. Over a four month time period, there were 4,780 alerts that were fired, 3,158 were for distinct patients, 485 alerts were acted on which resulted in 238 (49\%) patients referred for the clinical trial. The study found that using the EHR alerting process for clinical trials resulted in significant increases in the number of physicians 
participating in clinical trial recruitment process. In addition, this recruitment process minimized referral bias and extended recruitment to a wider patient population [4].

In Powell and Buchan's discussion, they suggest that there is potential for hypotheses creation and research study completion based on electronic records. What once was a tedious and manual process or clinical researchers can be done electronically, and perhaps automated. Powell and Buchan further state, "researchers and research managers much engage with EHR initiatives to realize ... benefits" [4, p. 3].

\section{COMPARISON OF BUSINESS INTELLIGENCE (BI) TO CLINICAL RESEARCH INTELLIGENCE (CRI)}

Golfarelli, Rizzi and Cella define Business Intelligence (BI) as "the process of turning data into information and then into knowledge" [2, p. 1]. This process is used for decision support and performance management in organizations. According to Turban, Sharda, Aronson, and King, the main objective of BI is to provide users with interactive access to data and provide business managers and analysts the ability to conduct analysis. They state, "By analyzing historical and current data, situations, and performance, decision-makers get valuable insights upon which they can base more information and better decisions" [5, p. 9]. Similarly, clinical researchers abstract or collect data through database reporting or patient record review. They use historical and current data, situations, and outcomes to determine potential issues and generate hypotheses and support studies.

The Business Intelligence (BI) framework is presented in an organizational business management context, focused on business topics such as market research, customer characteristics, and business performance. However, this same framework can be applied to clinical research field using information collected during patient care encounters. Normal transactions occur within the normal workflow processes such as patient registration, transcribed or structured reporting, computerized physician order entry (CPOE), and clinical documentation. Data is captured electronically and stored within the application database. Data is extracted or sent through a transaction interface (real-time or batch processing) to an operational data store or a data warehouse. Operational data store is defined as database that is used as a staging area prior to insertion in the data warehouse [5]. It is within a data warehouse that clinical researchers can use data extraction tools, data mining, and clinical research decision support to complement the research process.

\section{COMPARISON OF BUSINESS ANALYTICS (BA) TO CLINICAL RESEARCH ANALYTICS (CRA)}

Using decision support, data extraction, querying, and data mining are tools and techniques of business analytics. Business analytics is a term used to for the tools and techniques that are used to gather and analyze data for business and strategic decisions [5]. These same tools and techniques can also be used for gathering, collecting, and storing clinical research data, and categorized under clinical research intelligence (CLRI). Turban, Sharda, Aronson, and King identify three categories under Business Analytics (BA): 1) Information and Knowledge Discovery; 2) Decision Support and Intelligent Systems, and 3) Visualization. All three of these categories contribute to the framework for clinical research data needs [5].

Information and Knowledge Discovery uses OLAP (on-line analytical processing,) ad hoc queries, data mining, text mining, Web mining, and search engines [5]. All of these tools are useful and relevant to the clinical research data collection and analysis process. The second category of BA, Decision Support and Intelligent Systems, include tools and techniques such as decision support systems, statistical analysis, and data mining and predictive analysis [5]. These tools and techniques can be used for generating a hypothesis as well as data collection and analysis. Further, decision support systems, specifically Clinical Research Decision Support Systems (CRDSS), can be created for multiple purposes supporting the research goals and initiatives. The third category, BA, is Visualization which includes scorecards and dashboards. A similar concept and presentation of information may be useful to a clinical researcher. For example, one such application may be a dashboard reporting clinical trial progress or patient outcomes or trending.

A table of the business value of BI analytical applications demonstrate the analytic application and business question is presented in Appendix A. To demonstrate the similarities between business intelligence and clinical research intelligence, a clinical research value application table is appended for comparison purposes. 


\section{CLINICAL RESEARCH INFORMATICS (CRI)}

As electronic health records become more prevalent, the opportunity for clinical researchers presents offering a more optimal approach to clinical research processes. To take advantage of the opportunities electronic data offers and overcome challenges and barriers experienced by clinical researchers, Clinical Research Informatics (CRI) should strengthen as a discipline. As stated by Powell and Buchan, with the increase of electronic clinical documentation, clinical researchers should be engaged in the healthcare organization's initiatives and development to ensure that data needs are identified and met [4]. Clinical Research Informatics (CRI) offers opportunity to work through barriers such as obtaining data, deidentifying data, and funding strategies. In addition, the CRI can act as the liaison between EHR Information Technology (IT) teams and clinical researchers.

Establishing a Clinical Research Informatics (CRI) team in academic partnered or affiliated healthcare systems provides structure to tackle challenges in the research process and refine the data collection and analysis process (Appendix B). The position of Chief Medical Information Officer (CMIO) surfaced from EHR planning initiatives and implementations. Likewise, clinical researchers who worked in academic partnered or affiliated healthcare systems should establish the leadership role, Chief Research Information Officer (CRIO). This role can ensure adequate leadership for clinical research initiatives and sustainability, including clinical research decision support systems (CRDSS) to attain a new level in clinical research processes.

\section{CONCLUSION}

In response to the 2009 ARRA Healthcare Information Technology (HIT) initiatives, healthcare entities are adopting electronic health records. This transformation offers the potential for improved quality and increased patient safety to patients and an opportunity to improve public health. As this transformation occurs, clinical researchers should engage in the EHR initiatives and work in tandem with EHR and Information Technology teams to ensure business intelligence tools and techniques are utilized for research initiatives. To achieve this, research organizations should strengthen the Clinical Research Informatics (CRI) as a discipline. The CRI discipline can use Business Intelligence (BI) as a framework for leveraging clinical data captured during patient care encounters to optimize clinical research processes and approach to research studies. Clinical data can be transformed into knowledge with tools and techniques such as clinical research decision support systems (CRDSS), data mining, and ad hoc reports from clinical data warehouses.

\section{REFERENCES}

1. 2009 American Reinvestment and Recovery Act. Retrieved November 17, 2009 from http://frwebgate.access.gpo.gov/cgibin/getdoc.cgi?dbname $=111$ cong bills \& docid=f:h1enr.pdf

2. Golfarelli, M., Rizzi, S., Cella, I.(2004). Beyond Data Warehousing : What's Next in Business Intelligence . Retrieved March 1, 2010 from http://portal.acm.org/citation.cfm?id=1031 $\underline{763.1031765}$

3. Miller, R., \& Sim, I. (2004). Physician's Use of Electronic Medical Records: Barriers and Solutions. Health Affairs, $23,116-126$

4. Powell, J., Buchan, I. Electronic Health Records Should Support Clinical Research. JMIA. V.7. 2005. Retreived from http://www.cbi.nlm.nih.gov/pmc/articles/ PMC1550635/ on March 1, 2010

5. Turban, E., Sharda, R., Aronson, J. \& King, D. (2008). Business intelligence: a managerial approach. Upper Saddle River: Pearson PrenticeHall 
Appendix A: Business and Clinical Research Analytics Value Comparison

\begin{tabular}{|c|c|c|c|c|c|}
\hline \multicolumn{3}{|c|}{ Business Value of BI Analytical Applications } & \multicolumn{3}{|c|}{ Clinical Research Value of Analytical Application } \\
\hline $\begin{array}{l}\text { Analytic } \\
\text { Application }\end{array}$ & Business Question & Business Value & $\begin{array}{l}\text { Analytic } \\
\text { Application }\end{array}$ & $\begin{array}{l}\text { Research } \\
\text { Perspective }\end{array}$ & $\begin{array}{l}\text { Research } \\
\text { Value }\end{array}$ \\
\hline $\begin{array}{l}\text { Customer } \\
\text { segmentation }\end{array}$ & $\begin{array}{l}\text { What are their } \\
\text { markets and what } \\
\text { are their } \\
\text { characteristics? }\end{array}$ & $\begin{array}{l}\text { Personalize } \\
\text { customer } \\
\text { relationships for } \\
\text { higher customer } \\
\text { satisfaction and } \\
\text { retention }\end{array}$ & $\begin{array}{l}\text { Patient } \\
\text { segmentation }\end{array}$ & $\begin{array}{l}\text { What are their } \\
\text { services and } \\
\text { what are their } \\
\text { demographics } \\
\text { and medical } \\
\text { conditions? }\end{array}$ & $\begin{array}{l}\text { Correlate } \\
\text { clinical } \\
\text { findings such } \\
\text { as lab values } \\
\text { with conditions } \\
\text { to discover } \\
\text { new approach } \\
\text { to diagnosis } \\
\text { and treatment }\end{array}$ \\
\hline $\begin{array}{l}\text { Propensity to } \\
\text { buy }\end{array}$ & $\begin{array}{l}\text { Which customers } \\
\text { are most likely to } \\
\text { respond to my } \\
\text { promotion? }\end{array}$ & $\begin{array}{l}\text { Target customers } \\
\text { based on their } \\
\text { need to increase } \\
\text { loyalty }\end{array}$ & $\begin{array}{l}\text { Propensity to } \\
\text { comply }\end{array}$ & $\begin{array}{l}\text { How does } \\
\text { patient } \\
\text { compliance } \\
\text { affect } \\
\text { outcome? }\end{array}$ & $\begin{array}{l}\text { Target non- } \\
\text { compliant } \\
\text { population }\end{array}$ \\
\hline $\begin{array}{l}\text { Fraud } \\
\text { detection }\end{array}$ & $\begin{array}{l}\text { How can I tell } \\
\text { which transactions } \\
\text { are likely to be } \\
\text { fraudulent? }\end{array}$ & $\begin{array}{l}\text { Quickly } \\
\text { determine fraud } \\
\text { and take } \\
\text { immediate action } \\
\text { to minimize cost }\end{array}$ & Recruitment & $\begin{array}{l}\text { How can I } \\
\text { identify } \\
\text { clinical trial } \\
\text { candidates? }\end{array}$ & $\begin{array}{l}\text { Quickly } \\
\text { identify } \\
\text { candidates for } \\
\text { clinical trials }\end{array}$ \\
\hline $\begin{array}{l}\text { Customer } \\
\text { profitability }\end{array}$ & $\begin{array}{l}\text { What is the lifetime } \\
\text { profitability of my } \\
\text { customer? }\end{array}$ & $\begin{array}{l}\text { Make individual } \\
\text { business } \\
\text { interaction } \\
\text { decisions based } \\
\text { on the overall } \\
\text { profitability of } \\
\text { customers }\end{array}$ & Medical care value & $\begin{array}{l}\text { What is the } \\
\text { lifetime value } \\
\text { of screening } \\
\text { and } \\
\text { interventions? }\end{array}$ & $\begin{array}{l}\text { Studying } \\
\text { frequency of } \\
\text { screening } \\
\text { procedures to } \\
\text { determine } \\
\text { diagnostic } \\
\text { value }\end{array}$ \\
\hline $\begin{array}{l}\text { Customer } \\
\text { attrition }\end{array}$ & $\begin{array}{l}\text { Which customer is } \\
\text { at risk of leaving? }\end{array}$ & $\begin{array}{l}\text { Prevent loss of } \\
\text { high-value } \\
\text { customers and let } \\
\text { go of low-value } \\
\text { customers }\end{array}$ & Mortality & $\begin{array}{l}\text { Why are } \\
\text { patients dying? }\end{array}$ & $\begin{array}{l}\text { Prevent deaths } \\
\text { by researching } \\
\text { risk factors so } \\
\text { that high risk } \\
\text { patients can be } \\
\text { targeted for } \\
\text { diagnosis and } \\
\text { treatment }\end{array}$ \\
\hline $\begin{array}{l}\text { Channel } \\
\text { Optimization }\end{array}$ & $\begin{array}{l}\text { Which is the best } \\
\text { channel to reach my } \\
\text { customer in each } \\
\text { segment? }\end{array}$ & $\begin{array}{l}\text { Interact with } \\
\text { customers based } \\
\text { on their } \\
\text { preference and } \\
\text { your need to } \\
\text { manage cost }\end{array}$ & Study optimization & $\begin{array}{l}\text { What is the } \\
\text { best method to } \\
\text { collect data to } \\
\text { answer my } \\
\text { research } \\
\text { questions? }\end{array}$ & $\begin{array}{l}\text { Interact with } \\
\text { data base to } \\
\text { find patterns, } \\
\text { relationships, } \\
\text { and } \\
\text { correlations }\end{array}$ \\
\hline
\end{tabular}

Adapted from Business Value of BI Analytical Applications: Turban, Sharda, Aronson, \& King (2008) [Original Source: Ziama and Kasher (2004)] 


\section{Appendix B: Comparison of Business and Clinical Research Roles and Processes}

\begin{tabular}{|l|l|}
\hline Business & Clinical Research \\
\hline Chief Information Officer (CIO) & Chief Research Information Office (CRIO) \\
\hline Business Intelligence (BI) & Clinical Research Intelligence (CLRI) \\
\hline Business Analytics (BA) & Clinical Research Analytics (CRA) \\
\hline Decision Support Systems (DSS) & Clinical Research Support Systems (CRSS) \\
\hline
\end{tabular}

Business Process Roles and Processes Compared with Potential Clinical Research Informatics (CRI) 